\title{
Imaging Mass Spectrometry of Endogenous Polypeptides and Secondary Metabolites from Galls Induced by Root-Knot Nematodes in Tomato Roots
}

\author{
Eder Alves Barbosa, ${ }^{1,2,+}$ Mauro Ferreira Bonfim, Jr., ${ }^{2,3}$ Carlos Bloch, Jr.,, Gilbert Engler, ${ }^{4}$ \\ Thales Rocha, ${ }^{3}$ and Janice de Almeida Engler ${ }^{4,+}$ \\ ${ }^{1}$ Laboratório de espectrometria de massa, Embrapa Recursos Genéticos e Biotecnologia, PqEB, 70770-900, Brasília-DF, \\ Brazil; ${ }^{2}$ Laboratório de Síntese e Análise de Biomoléculas, Instituto de Química, Universidade de Brasília, 70910-900, Brasília- \\ DF, Brazil; ${ }^{3}$ Laboratório de Interação Molecular Planta-Praga, Embrapa Recursos Genéticos e Biotecnologia, PqEB; and \\ ${ }^{4}$ INRA, Université Côte d'Azur, CNRS, ISA, 06903, Sophia Antipolis, France
}

Accepted 10 April 2018.

Nematodes are devastating pests that infect most cultivated plant species and cause considerable agricultural losses worldwide. The understanding of metabolic adjustments induced during plant-nematode interaction is crucial to generate resistant plants or to select more efficient molecules to fight against this pest. Matrix-assisted laser desorption/ionization mass spectrometry imaging (MALDI-MSI) has been used herein for in situ detection and mapping endogenous polypeptides and secondary metabolites from nematode-induced gall tissue. One of the major critical features of this technique is sample preparation; mainly, the generation of intact sections of plant cells with their rigid cell walls and vacuolated cytoplasm. Our experimental settings allowed us to obtain sections without contamination of exogenous ions or diffusion of molecules and to map the differential presence of low and high molecular weight ions in uninfected roots compared with nematode-induced galls. We predict the presence of lipids in both uninfected roots and galls, which was validated by MALDI time-of-flight tandem mass spectrometry and high-resolution mass spectrometry analysis of lipid extracts. Based on the isotopic ion distribution profile, both esters and glycerophospholipids were predicted compounds and may be playing an important role in gall development. Our results indicate that the MALDI-MSI technology is a promising tool to identify secondary metabolites as well as peptides and proteins in complex plant tissues like galls to decipher molecular processes

Funding: E. A. Barbosa and M. F. Bonfim, Jr. have been supported by postdoctoral scholarships from Pesquisador Visitante Especial Conselho Nacional de Desenvolvimento Científico e Tecnológico (PVE CNPq) and Programa Nacional de Pós Doutorado da CAPES (grant number 1603966) and PVE CNPq, respectively.

Current address for Mauro Ferreira Bonfim, Jr.: EPAGRI, Estação Experimental de Urussanga, Rodovia SC 108, Bairro Estação, 88840-000, Urussanga-SC, Brazil.

${ }^{\dagger}$ Corresponding authors: Janice de Almeida Engler;

E-mail: janice.de-almeida@inra.fr; and

Eder Alves Barbosa; E-mail: bioederr@gmail.com

*The $\boldsymbol{e}$-Xtra logo stands for "electronic extra" and indicates that nine supplementary figures are published online.

(c) 2018 The American Phytopathological Society responsible for infection and maintenance of these feeding sites during nematode parasitism.

Plant-parasitic nematodes are devastating pathogens that infect most cultivated plant species and cause considerable agricultural losses worldwide. During parasitism, root-knot nematodes (RKN; Meloidogyne spp.) modify the vascular cell metabolism, inducing large feeding sites, named galls. These galls harbor five to nine hypertrophied giant-feeding cells and numerous proliferating neighboring cells, resulting in a typical root swelling. Gall cells are interconnected by plasmodesmata together with phloem and xylem elements to facilitate nutrient transport for nematode feeding (Hofmann et al. 2010). Giant cells are multinucleate due to the intense mitotic activity followed by nuclear enlargement caused by endoreduplication (de Almeida Engler et al. 1999, 2012). The cytoplasm of these nematode-feeding cells contains a dense cytoplasm filled with organelles, reflecting its high metabolic activity. The resulting multilayered cellular feeding structure encloses the nematodes until the end of its life cycle (from juvenile to adult female), and will finally deprive the plant of its nutrients (Jones and Northcote 1972).

The understanding of metabolic adjustments induced during plant-nematode interactions is crucial to generate resistant plants or to select more efficient tools to fight against this pest. Most studies involve transcriptomic and proteomic analyses (Barcala et al. 2012; Baldacci-Cresp et al. 2012), followed by mRNA in situ hybridizations (de Almeida Engler et al. 2009, 2012; Vieira et al. 2013). Although these strategies are useful to elucidate important features during the plant-nematode interaction, it is based on the indirect measurement of proteins or mRNA. Immunocytochemical methods have been applied to localize specific proteins present in galls and within nematodes (Banora et al. 2011; Clément et al. 2009; de Almeida Engler et al. 2004; Vieira et al. 2012). However, this technique remains limited to few types of macromolecules, it is costly, and it is not efficient to gain insight into small molecules such as metabolites.

Low molecular weight compounds, namely secondary metabolites, can play important roles in defense mechanisms against natural pests in plants. This class of molecules, including isoprenoids, phenylpropanoids, alkaloids, and fatty acids, can act in both constitutive and inducible defense mechanisms in plants against natural pests of plants (Cheng et al. 2007; Fujimoto et al. 2015; Vogt 2010; Ziegler and Facchini 2008). It is believed that secondary metabolites play a role in repelling and attracting RKN 
in a species-specific way (Williamson et al. 2009). However, the identification and characterization of candidate secondary metabolites is not an easy task. Up to now, there has been no reliable methodology describing the identification and localization of metabolites directly in nematode-induced galls.

A promising technique that can be applied to map molecules in biological tissues is matrix-assisted laser desorption/ionization mass spectrometry imaging (MALDI-MSI) (Caprioli et al. 1997; Chaurand et al. 1999, 2006). The main feature of MALDI-MSI is the ability to determine the spatial distribution of compounds and to identify known and unknown molecules with minimal tissue manipulation. MALDI-MSI has been applied to study and map molecules of different biological sources such as peptides of frog skin secretion (Barbosa et al. 2015; Brand et al. 2006; Magalhães et al. 2008) and rat pituitary cells (Sosnowski et al. 2015), as well as of food metabolome (Ibáñez et al. 2013) and plant metabolites such as hesperidin and rutin present in leaves and stems of Citrus limonia (Kaspar et al. 2011; Soares et al. 2015).

In recent years, the use of MALDI-MSI applied to plant tissues has increased and is becoming a useful tool for the identification of molecules from any tissue type. The main application has involved the detection and localization of small molecules, mainly metabolites (Dong et al. 2016; Lee et al. 2012) such as carbohydrates (Veličković et al. 2014), lipids (Horn et al. 2012, 2013; Zaima et al. 2010), alkaloids (Lu et al. 2010), and phenolics (Becker et al. 2014; Franceschi et al. 2012). Although analysis involving MALDI-MSI of peptides and proteins in plants has been considered particularly challenging in general (Dong et al. 2016), relatively few studies describe such application (Gemperline et al. 2016; Grassl et al. 2011; Kaspar et al. 2011; Peukert et al. 2014).

The value of MALDI-MSI technology to study plantmicrobe interactions has been demonstrated in previous reports. MALDI-MSI was applied to map hesperidin, a flavanone produced by citrus plants associated with Xylella fastidiosa infections, on petiole and leaf transversal sections of infected and uninfected plants, suggesting that hesperidin acts as a phytoanticipin in plant-pathogen interactions (Soares et al. 2015). In another work, MALDI-MSI results indicated the relevance of cyclopeptides in endophyte-endophyte interspecies neighbor communication by mapping these molecules in bulb tissue of Narcissus tazetta plants (Wang et al. 2015). Finally, organic acids, amino acids, sugars, lipids, flavonoids, and their conjugates were identified and mapped by MALDI-MSI in root nodules formatted by symbiotic associations between Medicago truncatula and Sinorhizobium meliloti, highlighting the benefits of MALDI-MSI experiments applied to plant-microbe interaction studies (Ye et al. 2013).

Herein, we describe a first application of MALDI-MSI for identification and determination of the spatial distribution of peptides, proteins, and secondary metabolites present in galls of tomato roots (Solanum lycopersicum) induced by the RKN Meloidogyne incognita. An optimized tissue preparation protocol for galls was established, allowing the mapping of molecules differentially distributed between infected and uninfected root tissues. We proposed the structure of 18 low molecular weight ions (LMWI), of which 3 were confirmed by additional experiments. These were characterized as lipid molecules, specifically glycerophospholipids (GPL), suggesting that GPL may be involved in the processes related to infection and maintenance of nematode feeding cells as well as for root development.

\section{RESULTS}

\section{Sample preparation.}

Galls at different time points (14 to 30 days after inoculation [DAI]) were collected from nematode-infected tomato roots for sectioning for MALDI-MSI experiments (Fig. 1A). At 14 DAI, galls are still developing and, at 30 DAI, galls are fully differentiated and have stopped expanding although, at both stages, they present high metabolic activity. Initially, we used a vibratome to generate thick slices, which ranged from 50 to $300 \mu \mathrm{m}$, with the best morphology observed at a thickness of $120 \mu \mathrm{m}$ (Fig. 1B). Slices containing moderately fixed giant cells, floating on distilled water, were selected using a stereomicroscope and placed on glass slides in water, coverslipped, and observed in bright-field microscopy to evaluate tissue and section quality. Images were recorded (Fig. 1B) and sections
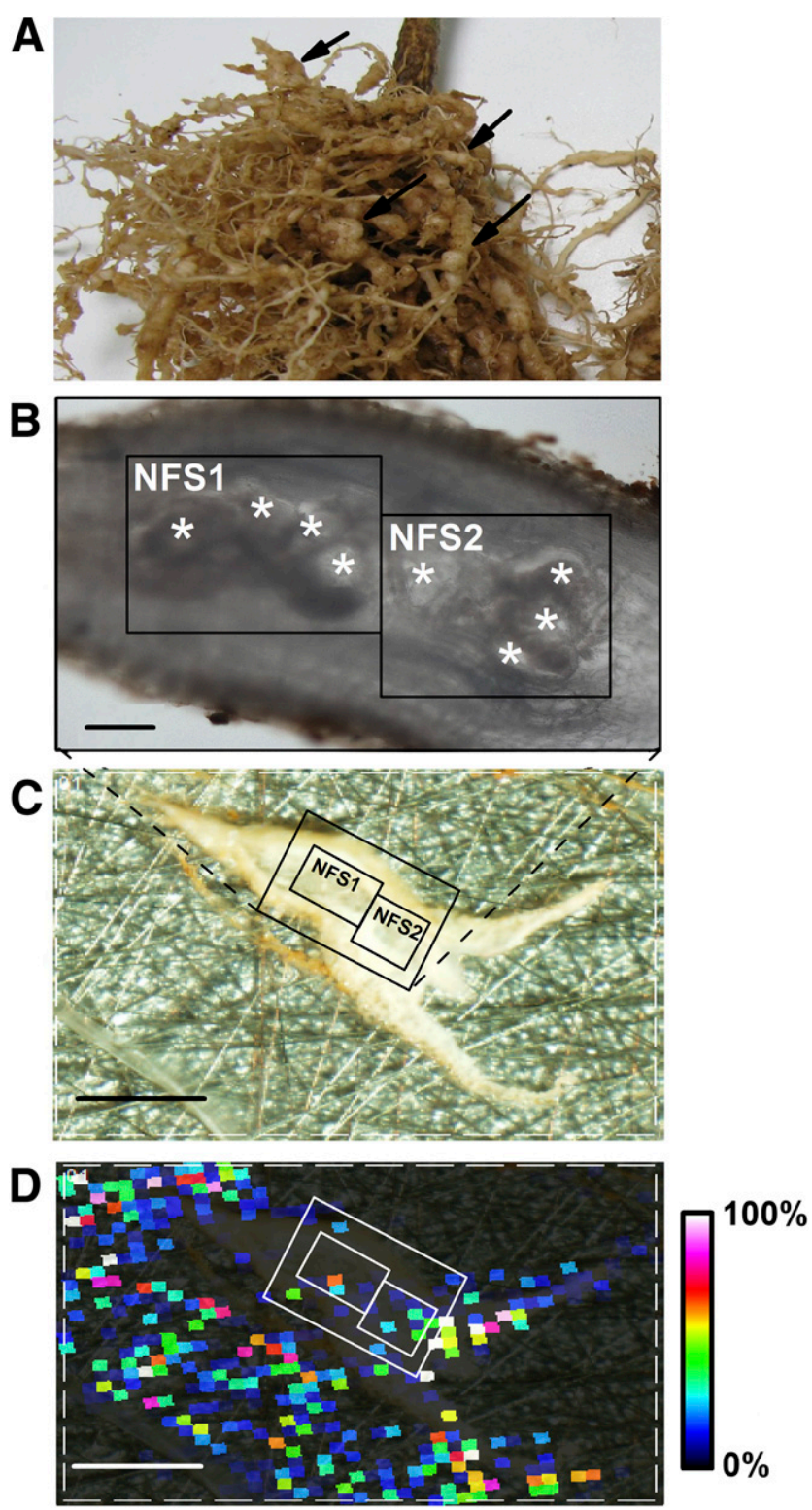

Fig. 1. Matrix-assisted laser desorption/ionization (MALDI) mass spectrometry imaging applied to map molecules having high molecular mass in a nematode-induced gall. A, Image of a nematode-infected root system, some of them indicated by arrows. B, Micrograph showing a gall 14 days after inoculation sectioned with a vibratome containing giant cells. C, Image for acquisition software use (FlexImaging 4.0) of the same section after transferring to the MALDI plate. Square shows the fraction of the gall shown in B and D. D, Distribution of ions identified on the gall tissue. Note that most of the ions are shifted to the surroundings of the gall section, indicating that ions moved out of the sample. The vertical scale bar represents ion signal intensity. NFS $=$ nematode feeding site, asterisk $\left(^{*}\right)=$ giant cell, and bars $=400 \mu \mathrm{m}$. 
were subsequently transferred to a MALDI target plate. Success of tissue preservation during transfer was monitored by taking another micrograph to be used for software acquisition (Fig. 1C). Distribution of ions observed on gall tissue indicated a loss and apparent mobility of cellular content, suggesting that molecules were not properly fixed in the tissue, making this strategy inappropriate to MALDI-MSI experiments (Fig. 1D).

To avoid the problem of diffusion and loss of cellular content as observed in mildly fixed and vibrosliced gall tissue, galls were alternatively embedded in egg yolk, gelatin, or agarose and submitted to cryosectioning at $-15^{\circ} \mathrm{C}$. Although these procedures are more delicate to preserve tissue integrity, they were less prone to component diffusion. Only blocks prepared with egg yolk enabled us to obtain sections with a thickness of down to $10 \mu \mathrm{m}$. Blocks with galls embedded in gelatin or agarose became quickly brittle under low temperature for cryosectioning. When egg yolk was used as an embedding medium, samples presented a good texture for sectioning. Because thinner sections down to $10 \mu \mathrm{m}$ resulted in holes in the larger giant cells and loss of cytoplasm, gall cryosections were
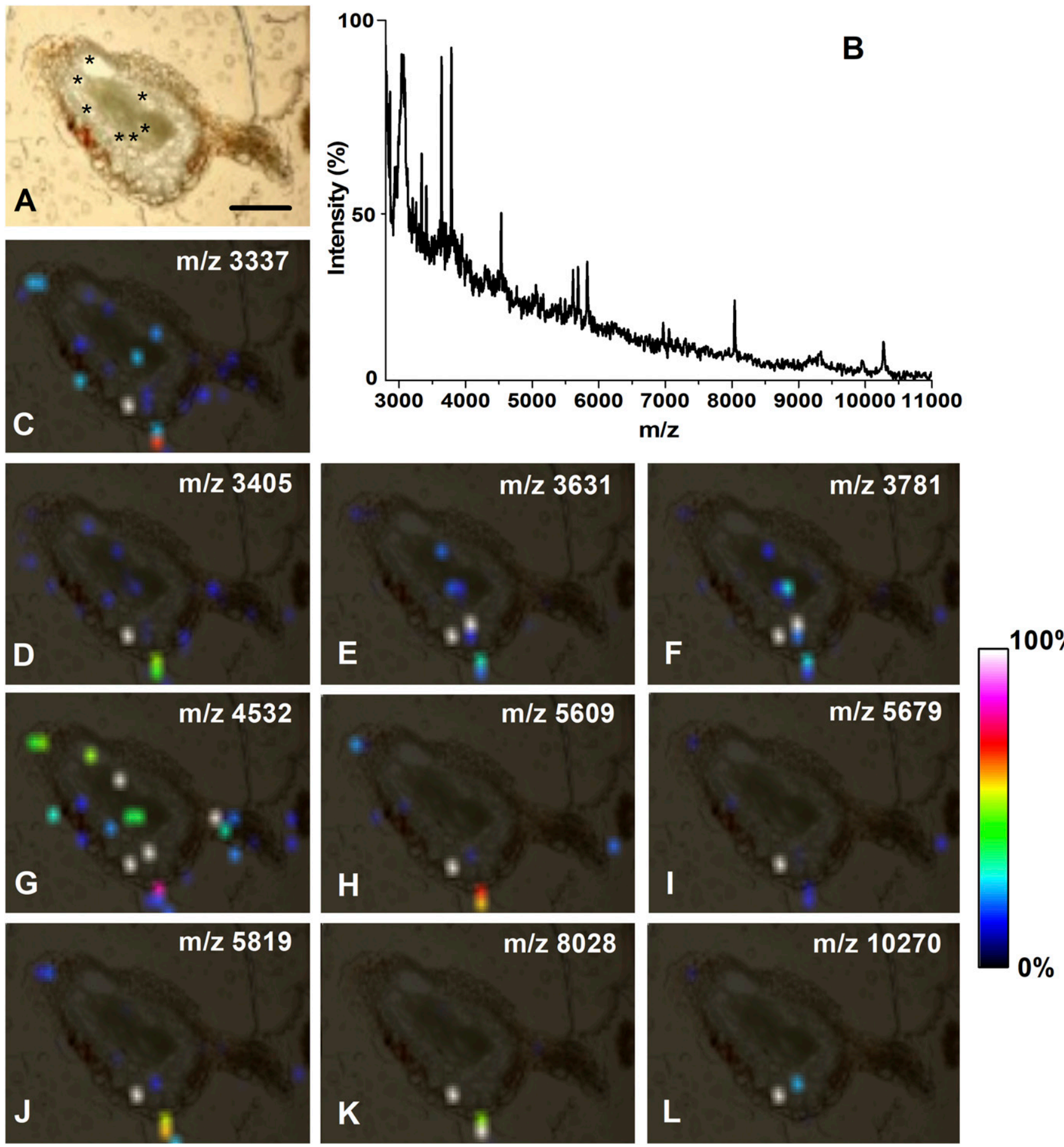

Fig. 2. Matrix-assisted laser desorption/ionization mass spectrometry imaging applied to map molecules having high molecular mass in a nematode-induced gall. A, Micrograph showing a gall cryosection 14 days after inoculation containing intact giant cells. B, Overall resulting mass spectrum. $\mathbf{C}$ to $\mathbf{L}$, Spatial localization of the different ions identified. The vertical scale bar represents ion signal intensity. Asterisk, giant cell. Bar $=400 \mu \mathrm{m}$. 
increased to $90 \mu \mathrm{m}$ in thickness to solve this problem, avoiding cell damage and making the process of sample preparation for MALDI-MSI more suitable (Supplementary Fig. S1). Moreover, after sectioning approximately 30 galls at 14 and $30 \mathrm{DAI}$, it was shown to be easier to obtain intact sections containing giant cells at the first time point. As such, galls 14 DAI were chosen for all subsequent experiments.

\section{MALDI-MSI of high molecular weight ions}

on galls infected by $M$. incognita.

Subsequent to microscopy observation, intact gall sections were submitted to matrix deposition using an artistic airbrush and submitted to MALDI-MSI of high molecular weight ions (HMWI). All matrices tested promoted ionization of molecules at different intensity levels; however, sinapinic acid (SA) proved to be more efficient to generate HMWI signals across tissues over the $\mathrm{m} / \mathrm{z}$ range analyzed. Therefore, it was used to investigate peptides and proteins in nematode feeding sites (Fig. 2A and B). Ten well-resolved ions with distinct $\mathrm{m} / \mathrm{z}$ values $(3,000$ to 11,000$)$ were mapped in developing galls (Fig. 2C to L). The analysis of galls obtained from different plants showed global mass spectra presenting a similar pattern of ionization and ions distribution (Supplementary Fig. S2). The global mass spectrum generated from MALDI-MSI of HMWI of uninfected roots is visibly different from that obtained from galls (Supplementary Fig. S3) and more ions were detected in uninfected roots compared with galls.

MALDI-MSI of low molecular weight ions on galls infected by $M$. incognita.

Following microscopy observation, intact sections were submitted to MALDI-MSI of LMWI with and without matrix deposition. The global spectrum obtained from analyzes
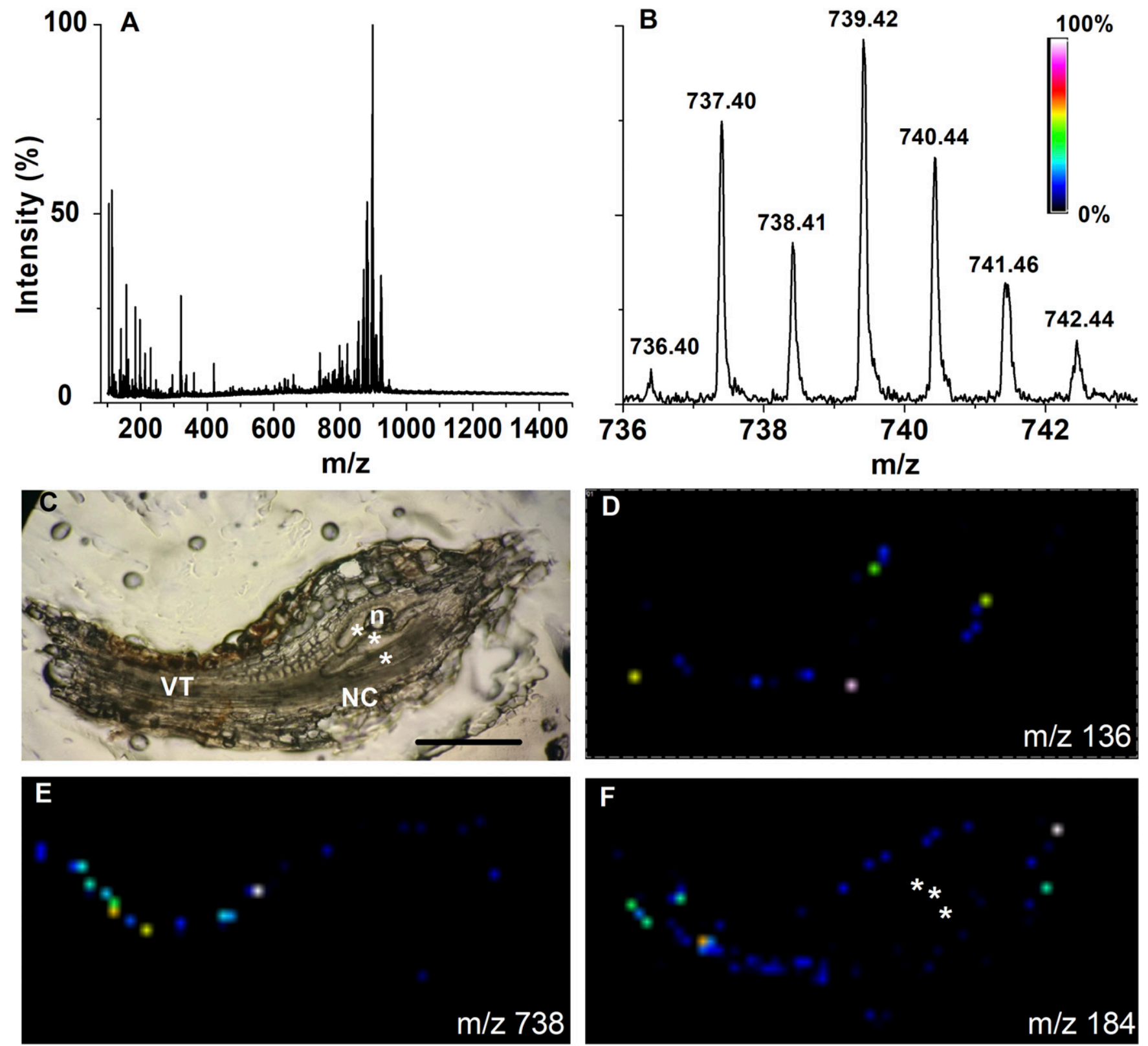

Fig. 3. Matrix-assisted laser desorption/ionization mass spectrometry imaging applied to map compounds having low molecular mass in a nematode-induced gall. A, Overall resulting mass spectrum of ions from infected roots. B, Isotopic profile of ions at $\mathrm{m} / \mathrm{z} 736.40$ and 738.41 . C, Micrograph showing a gall cryosection containing giant cells 14 days after inoculation. D, Ion located in the vascular tissue, giant cells, and neighboring cells. E, Ion located in epidermal cells. F, Ion located in epidermal cells, vascular tissue, giant cells, and neighboring cells. The vertical scale bar represents ion signal intensity. Definitions: $\mathrm{n}=$ nematode, $\mathrm{VT}=$ vascular tissue, $\mathrm{NC}=$ neighboring cells, asterisk $(*)=$ giant cell, and bar $=320 \mu \mathrm{m}$. 
performed without matrix deposition on a thick gall of $14 \mathrm{DAI}$ cryosectioned (Fig. 3A) revealed the presence of several ions with different intensity values, allowing us to map approximately 44 molecules with $\mathrm{m} / \mathrm{z}$, values ranging from 104.18 to 923.83 (Fig. 3; Supplementary Fig. S4). The isotopic distribution patterns seen for almost all ions present in all spectra acquired for LMWI was interesting. This isotopic profile has the base peak represented by the second isotope rather than the first, as was shown for the ions at $m / z 736.40$ and 738.41 (Fig. 3B). Concerning the spatial location of low molecular mass molecules in galls (Fig. 3C), some ions were localized in vascular cells and cells neighboring giant cells (Fig. 3D) or, most likely, in epidermal cells (Fig. 3E), while others were widespread in all cell types, including giant cells (Fig. 3F).

The global mass spectra resulting from MALDI-MSI acquisitions performed in sections of uninfected roots and galls 14 DAI
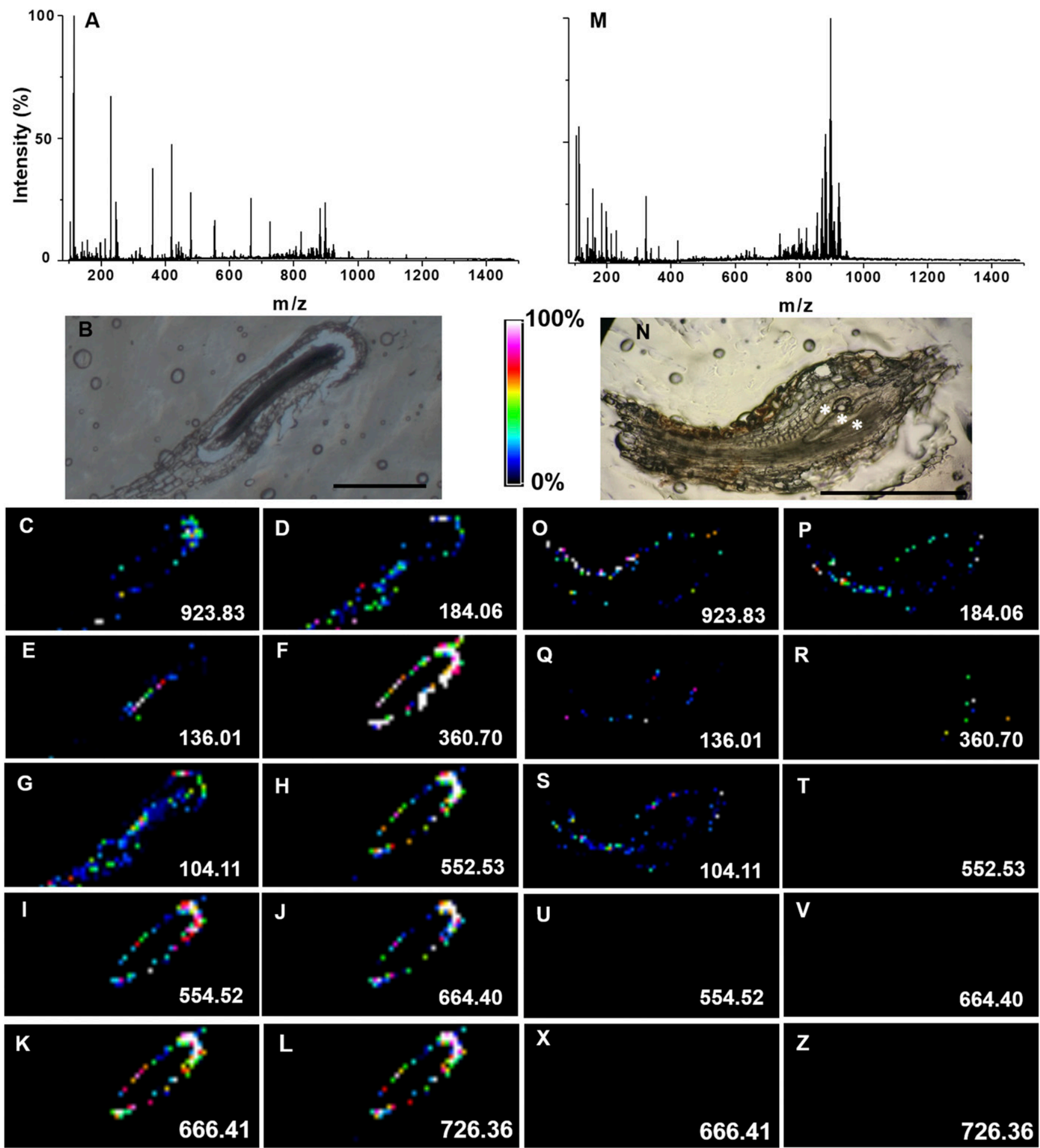

Fig. 4. Matrix-assisted laser desorption/ionization mass spectrometry imaging (MALDI-MSI) applied to map compounds having low molecular mass in $\mathbf{A}$ to $\mathbf{L}$, uninfected roots and $\mathbf{M}$ to $\mathbf{Z}$, a nematode-induced gall. $\mathbf{A}$ and $\mathbf{M}$, Global mass spectra obtained. $\mathbf{B}$ and $\mathbf{N}$, Micrographs showing the root and gall cryosections, respectively, subjected to MALDI-MSI analysis. Spatial location of different ions identified for $\mathbf{C}$ to $\mathbf{L}$, an uninfected root and $\mathbf{O}$ to $\mathbf{Z}$, a gall. The vertical scale bar represents ion signal intensity. Asterisk $(*)=$ giant cell and bar $=600 \mu \mathrm{m}$ 
have different ion profiles for an uninfected root (Fig. 4A and B) and for a gall (Fig. 4M and N). Our results revealed that some ions restricted to epidermal cells are similarly distributed in uninfected root cells (Fig. 4C) and galls (Fig. 4O). Other ions are located at the epidermis and vascular cells of uninfected roots (Fig. 4D and G) and gall cells (Fig. 4P and S). In addition, certain ions are present only in the vascular tissue, as shown for an uninfected root (Fig. 4E) and for a gall (Fig. 4Q). However, particular ions showed a major distribution in uninfected roots (Fig. 4F) compared with infected roots (Fig. 4R). Although we did not detect ions exclusively present in galls, certain ions mainly present in epidermal cells were found exclusively in uninfected roots (Fig. $4 \mathrm{H}$ to $\mathrm{L}$ and $\mathrm{T}$ to $\mathrm{Z}$ ).

Aiming to predict structures related to the LMWI detected during our MALDI-MSI experiments, after research in the literature and in the metabolic database Lipid Maps (Sud et al. 2007), the spectra acquired were meticulously analyzed according to the mass value, isotopic distribution pattern, and biological significance of tissue localization. Thus, we proposed the structure of $18 \mathrm{LMWI}$, and almost all have been characterized as GPL molecules, in addition to two fatty acyls and two naturally positive charged molecules: a choline and a phosphocholine (PC) (Table 1).

The MALDI-MSI analyses performed after 2,5-dihydroxy benzoic acid (DHB) matrix deposition by sublimation on two distinct uninfected root sections and galls 14 DAI revealed approximately 36 ions with a similar pattern of distribution. The exception was the ion $\mathrm{m} / \mathrm{z} 235.2$ that was observed only in galls (Supplementary Figs. 5 and 6).

\section{Lipid extraction and identification.}

To confirm whether LMWI identified in the MALDI-MSI experiments are of lipid nature ionized as lithium adduct and to give more confidence to the predicted structures, lipid extraction of uninfected roots was performed. Lipid extracts were analyzed by MALDI time-of-flight mass spectrometry (TOF-MS) in the reflective positive mode of acquisition and ions were selected for fragmentation in the LIFT mode (tandem mass spectrometry [MS/MS]). The spectra obtained from the MALDI-MSI experiment (Fig. 5A) and from lipid extract of uninfected roots (Fig. 5B) shared molecules with similar isotopic distribution ionized as lithium adduct although, globally, they are slightly different (Supplementary Fig. S7). The adduct $\left[\mathrm{M}+{ }^{7} \mathrm{Li}\right]^{+}=788.6$ was selected as precursor ion for MS/MS experiments and the interpretation of the resulting spectrum (Fig. 5C) revealed ions corresponding to the fragmentation of a glycerophosphocholine (GPC), a GPL. Molecules of this class consist of a glycerol to which two fatty acid (FA) chains are attached as esters to sn- 1 and sn-2 carbon positions. Here, FA chains were designed to have 18 carbons with two unsaturations (18:2/18:2). At sn-3 carbon, a phosphoric acid is linked in the same way and a positively charged quaternary ammonium bound to the phosphate (Fig. 5C, top). We also did the characterization of other GPC from uninfected root extract, in addition to a PC (Supplementary Fig. S8).

The lipid extract was analyzed by high-resolution MS aiming to determine the accurate masses of adducts submitted to MALDITOF-MS/MS experiments and corroborate spectra interpretations by determining the mass accuracy. Two of the adducts fragmented by MALDI experiments were evaluated by electrospray ionization quadrupole (ESI-Q)-TOF-MS as well $\left(\left[\mathrm{M}+{ }^{7} \mathrm{Li}\right]^{+}=\right.$ 788.5780 and $\left.\left[\mathrm{M}+{ }^{7} \mathrm{Li}\right]^{+}=764.5781\right)$. The molecular formula of the structures related to these ions were $\mathrm{C}_{44} \mathrm{H}_{80} \mathrm{NO}_{8} \mathrm{P}$ and $\mathrm{C}_{42} \mathrm{H}_{80} \mathrm{NO}_{8} \mathrm{P}$, resulting in a mass accuracy of 0.2 and $0.1 \mathrm{ppm}$, respectively (Supplementary Fig. S9).

\section{Protein extraction and identification.}

In order to test whether HMWI identified by MALDI-MSI in galls can be isolated for future characterization, protein extraction was performed. Galls were triturated and subjected to peptide/protein extraction using a solution of Milli-Q $\mathrm{H}_{2} \mathrm{O}$ / acetonitrile. The solution was centrifuged and the supernatant content was fractionated by ultrafast liquid chromatography (UFLC) (Fig. 6). Chromatographic fractions were collected and analyzed by MALDI-TOF-MS in the linear positive mode of acquisition. The $\mathrm{m} / \mathrm{z}$ values of ions identified in all chromatographic fractions analyzed are presented in Table 2.

\section{DISCUSSION}

To our knowledge, the MALDI-MSI-based approach was applied here for the first time to investigate polypeptides and metabolites from tomato plant roots and nematode-induced

Table 1. Structure of low molecular ions predicted ${ }^{\mathrm{a}}$

\begin{tabular}{|c|c|c|c|c|c|}
\hline Adduct & Molecular formula & $m / z^{\mathrm{T}}$ & $m / z^{\mathbf{E x}}$ & Category & Subclass or name \\
\hline$[\mathrm{M}]^{+}$ & $\mathrm{C}_{5} \mathrm{H}_{14} \mathrm{NO}$ & 104.10699 & 104.13 & Quaternary ammonium salt & Choline $^{b}$ \\
\hline$[\mathrm{M}]^{+}$ & $\mathrm{C}_{5} \mathrm{H}_{15} \mathrm{NO}_{4} \mathrm{P}$ & 184.07332 & 184.04 & & Phosphocholine \\
\hline$\left[\mathrm{M}+{ }^{7} \mathrm{Li}\right]^{+}$ & $\mathrm{C}_{35} \mathrm{H}_{64} \mathrm{NO}_{8} \mathrm{P}$ & 664.45153 & $664.46^{*}$ & Glycerophospholipids & Diacylglycerophospho-ethanolamines \\
\hline$\left[\mathrm{M}+{ }^{7} \mathrm{Li}\right]^{+}$ & $\mathrm{C}_{35} \mathrm{H}_{66} \mathrm{NO}_{8} \mathrm{P}$ & 666.46814 & $666.46^{*}$ & Glycerophospholipids & Diacylglycerophospho-ethanolamines \\
\hline$\left[\mathrm{M}+{ }^{7} \mathrm{Li}\right]^{+}$ & $\mathrm{C}_{39} \mathrm{H}_{78} \mathrm{NO}_{8} \mathrm{P}$ & 726.56205 & $726.44^{*}$ & Glycerophospholipids & $\begin{array}{l}\text { Diacylglycerophosphocholines or } \\
\text { diacylglycerophospho-ethanolamines }\end{array}$ \\
\hline$\left[\mathrm{M}+{ }^{7} \mathrm{Li}\right]^{+}$ & $\mathrm{C}_{50} \mathrm{H}_{98} \mathrm{O}_{2}$ & 737.77225 & $737.4^{*}$ & Fatty acyls & Wax esters \\
\hline$\left[\mathrm{M}+{ }^{6} \mathrm{Li}\right]^{+}$ & $\mathrm{C}_{50} \mathrm{H}_{100} \mathrm{O}_{2}$ & 738.78691 & 738.41 & Fatty acyls & Wax esters \\
\hline$\left[\mathrm{M}+{ }^{7} \mathrm{Li}\right]^{+}$ & $\mathrm{C}_{44} \mathrm{H}_{80} \mathrm{O}_{8} \mathrm{P}$ & 788.57770 & $788.58 *$ & Glycerophospholipids & Diacylglycerophosphocholines ${ }^{\mathrm{b}}$ \\
\hline$\left[\mathrm{M}+{ }^{6} \mathrm{Li}\right]^{+}$ & $\mathrm{C}_{47} \mathrm{H}_{91} \mathrm{O}_{10} \mathrm{P}$ & 852.64956 & 852.65 & Glycerophospholipids & Diacylglycerophosphoglycerols \\
\hline$\left[\mathrm{M}+{ }^{7} \mathrm{Li}\right]^{+}$ & $\mathrm{C}_{48} \mathrm{H}_{93} \mathrm{O}_{10} \mathrm{P}$ & 867.66620 & $867.61 *$ & Glycerophospholipids & Diacylglycerophosphoglycerols \\
\hline$\left[\mathrm{M}+{ }^{6} \mathrm{Li}\right]^{+}$ & $\mathrm{C}_{48} \mathrm{H}_{95} \mathrm{O}_{10} \mathrm{P}$ & 868.68086 & 868.61 & Glycerophospholipids & Diacylglycerophosphoglycerols \\
\hline$\left[\mathrm{M}+{ }^{6} \mathrm{Li}\right]^{+}$ & $\mathrm{C}_{49} \mathrm{H}_{93} \mathrm{O}_{10} \mathrm{P}$ & 878.66521 & 878.66 & Glycerophospholipids & Diacylglycerophosphoglycerols \\
\hline$\left[\mathrm{M}+{ }^{6} \mathrm{Li}\right]^{+}$ & $\mathrm{C}_{49} \mathrm{H}_{95} \mathrm{O}_{10} \mathrm{P}$ & 880.68086 & 880.67 & Glycerophospholipids & Diacylglycerophosphoglycerols \\
\hline$\left[\mathrm{M}+{ }^{6} \mathrm{Li}\right]^{+}$ & $\mathrm{C}_{47} \mathrm{H}_{83} \mathrm{O}_{13} \mathrm{P}$ & 892.57170 & 892.61 & Glycerophospholipids & Diacylglycerophosphoinositols \\
\hline$\left[\mathrm{M}+{ }^{7} \mathrm{Li}\right]^{+}$ & $\mathrm{C}_{50} \mathrm{H}_{95} \mathrm{O}_{10} \mathrm{P}$ & 893.68185 & $893.63 *$ & Glycerophospholipids & Diacylglycerophosphoglycerols \\
\hline$\left[\mathrm{M}+{ }^{6} \mathrm{Li}\right]^{+}$ & $\mathrm{C}_{47} \mathrm{H}_{85} \mathrm{O}_{13} \mathrm{P}$ & 894.58735 & 894.64 & Glycerophospholipids & Diacylglycerophosphoinositols \\
\hline$\left[\mathrm{M}+{ }^{6} \mathrm{Li}\right]^{+}$ & $\mathrm{C}_{50} \mathrm{H}_{97} \mathrm{O}_{10} \mathrm{P}$ & 894.69651 & 894.64 & Glycerophospholipids & Diacylglycerophosphoglycerols \\
\hline$\left[\mathrm{M}+{ }^{6} \mathrm{Li}\right]^{+}$ & $\mathrm{C}_{47} \mathrm{H}_{87} \mathrm{O}_{13} \mathrm{P}$ & 896.60300 & 896.63 & Glycerophospholipids & Diacylglycerophosphoinositols \\
\hline$\left[\mathrm{M}+{ }^{6} \mathrm{Li}\right]^{+}$ & $\mathrm{C}_{51} \mathrm{H}_{97} \mathrm{O}_{10} \mathrm{P}$ & 906.69651 & 906.72 & Glycerophospholipids & Diacylglycerophosphoglycerols \\
\hline$\left[\mathrm{M}+{ }^{6} \mathrm{Li}\right]^{+}$ & $\mathrm{C}_{52} \mathrm{H}_{99} \mathrm{O}_{10} \mathrm{P}$ & 920.71216 & 820.67 & Glycerophospholipids & Diacylglycerophosphoglycerols \\
\hline
\end{tabular}

${ }^{\text {a }}$ Superscripts $\mathrm{T}=$ theoretical value and Ex $=$ experimental value. An asterisk $(*)$ indicates that the $\left[\mathrm{M}+{ }^{7} \mathrm{Li}\right]^{+}$adduct was used instead $\left[\mathrm{M}+{ }^{6} \mathrm{Li}\right]^{+}$because the second presented very low intensity.

${ }^{\mathrm{b}}$ Confirmed by tandem mass spectrometry experiment. 
galls. In this study, we were able to detect molecules of low and high molecular weight in nematode-induced galls in tomato roots and to predict the structure of some LMWI. The procedure was applied on thick gall sections and compared with uninfected tomato roots. Tomato is a natural RKN host, and the MALDI-MSI methodology was used to investigate key molecules such as proteins and peptides as well as secondary metabolites that participate in the mechanisms of infection, development, and maintenance of galls induced by these nematodes. Information generated by MALDI-MSI can be potentially applied for the development of novel strategies to obtain nematode-resistant plants or to identify target compounds.

Using egg yolk to mount galls for cryostat sectioning.

In order to be able to subject plant tissues to MALDI-MSI, several precautions have to be considered with respect to sample fixation, embedding, sectioning, and mounting. Mainly, the presence of a rigid cell wall, aqueous vacuoles, and air pockets can make sectioning problematic. The use of classical fixatives such as aldehydes can lead to changes in the mass of molecules, thereby interfering with accurate interpretation of results. We showed that the vibroslice method was ineffective in preventing molecule diffusion across tissues during the process of sectioning. Although a different fixation regime might yield better results for vibroslice approach, we opted for an alternative method based on cryosectioning.

Cryosectioning has been shown to be far more effective in preserving the location of molecules in nematode-induced galls. This method appeared crucial to avoid poor signal and unwanted polymer signals in mass spectra (Chaurand et al. 2006; Sosnowski et al. 2015) of our samples analyzed by MALDI-MSI. Thus, herein, the use of egg yolk to support tissues for MALDI-MSI of compounds having an $\mathrm{m} / \mathrm{z}$ range of 3,000 to 11,000 or secondary metabolites did not interfere with the ionization of endogenous molecules, and ions related to molecules that could be potentially present in egg yolk were not observed, corroborating previous results observed in animal tissues such as rat pituitary cells (Sosnowski et al. 2015).

To obtain intact giant cells, cryosections of $90 \mu \mathrm{m}$ were generated, instead of the conventional 10 to $60 \mu \mathrm{m}$ generally used for plant tissues (Bencivenni et al. 2014; Grassl et al. 2011; Kusari et al. 2014; Mullen et al. 2005; Soares et al. 2015;
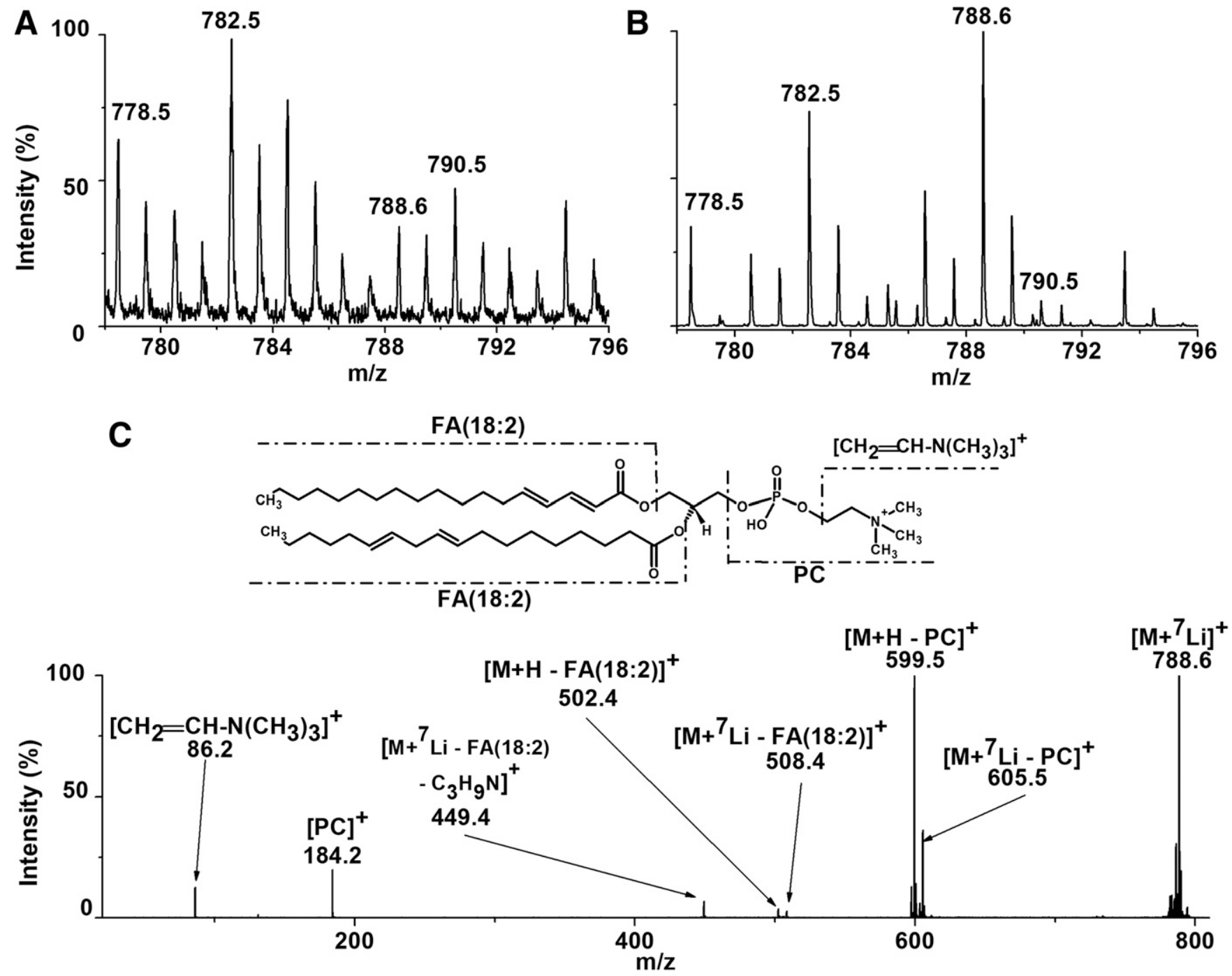

Fig. 5. Characterization of a glycerophospholipid (glycerophosphocholine [GPC]) from uninfected tomato root by matrix-assisted laser desorption/ ionization time-of-flight tandem mass spectrometry (MALDI-TOF MS/MS). Mass spectra from A, MALDI MS imaging of uninfected root after cryosectioning and B, MALDI-TOF MS of uninfected root lipid extract in the same mass range showing the ion at $m / z$ 788.6. C, MS/MS spectrum of the precursor ion $\left[\mathrm{M}+{ }^{7} \mathrm{Li}\right]^{+}=788.6$ and showing all fragment ions corresponding to the fragmentation of GPC (18:2/18:2) (top). All peaks were assigned according to loss and adduct involved. Unsaturation position was only placed for illustrative purpose because they cannot be set by this method. PC $=$ phosphocholine and FA = fatty acid. 
Veličković et al. 2014). Nematode-induced giant-feeding cells are significantly larger than other cells present in Arabidopsis tissues and harbor a large volume of water, also interfering with the cryosectioning procedure. Manipulating young galls (up to 14 DAI) also was found to be far more suitable to obtain intact sections containing well-fixed giant cells and their contents. In addition, this time point is characterized by cells with a high cell cycle (de Almeida Engler et al. 1999) and metabolic activity (Baldacci-Cresp et al. 2012, 2015; Jones 1981). Therefore, molecules which are potentially important for this susceptible interaction will be most likely present during this phase of gall development.

\section{MALDI-MSI of HMWI to identify proteins related to root infection by $M$. incognita.}

Although hundreds of molecules can be present in a tissue sample, the MALDI-MSI technique can preferentially detect some ions more efficiently due to factors such as their concentration and ionization capacity. Thus, the global mass spectra resulting from HMWI acquisition of uninfected roots suggest a facet of metabolic adjustment promoted by the plant host during nematode infection, herein characterized by a downregulation of some polypeptides. Indeed, transcriptomic analysis has suggested that these metabolic changes are characterized by the overexpression or inhibition of molecules (Barcala et al. 2010; Portillo et al. 2013; Shukla et al. 2018; Weiß et al. 2017). This is in accordance with our findings, although gene expression is subject to fluctuations during the infection process. Probably, each downregulated protein in galls under the conditions tested has a specific biological significance and its concentration is finely adjusted during nematode parasitism. Their presence and concentration in feeding sites will most likely characterize the emergence and maintenance of galls.

Another hypothesis to explain the protein downregulation is that some of these polypeptides might be ingested by the nematode as a nutrient source via feeding tubes. Nematodes constantly inject secretions to maintain the feeding site, and are nourished on molecules present in these feeding cells (Jones and Northcote 1972) to be able to develop and lay eggs.

\section{MALDI-MSI of LMWI performed without matrix application revealed molecules present exclusively in noninfected roots.}

Among the 44 well-resolved LMWI identified by MALDIMSI without matrix application, a cluster of ions $(\mathrm{m} / \mathrm{z}, 850$ to 950) presented in all tissues analyzed showed a pattern of ion distribution similar to that of natural lipids ionized as lithium adduct by MALDI-MS (Cerruti et al. 2011; Vrkoslav et al. 2009, 2010). Indeed, the isotopic pattern presented by these ions matched those expected for lithium adducts in the mass spectra, characterized mainly by a peculiar isotope abundance of ${ }^{6} \mathrm{Li}(7,59 \%)$ and ${ }^{7} \mathrm{Li}(92,41 \%)$ (Cvačka and Svatos 2003; Kaftan et al. 2014). Therefore, because tomato roots have a relatively high concentration of lithium salts (Bach and Gallicchio 1990; Schrauzer 2002), we predicted the structures of lipids that were imaged on infected and noninfected tomato roots based on their monoisotopic masses. The predicted molecule at $\left[\mathrm{M}+{ }^{7} \mathrm{Li}\right]^{+}=738.41$ belongs to a lipid group known as wax esters that, in plants, is present in the epicuticular layer and prevents nonstomatal water loss (Kunst and Samuels 2003). Although it is impossible to predict the exact structure of this ion by a simple MS experiment, this lipid was found by our MALDI-MSI acquisition in the epidermal cells, where they might act to prevent water loss of galls.

Three of the five ions exclusively found in uninfected roots $(\mathrm{m} / \mathrm{z}$ 664, 666, and 726) were predicted as GPL. Although we do not predict the structures of the other two ions $(\mathrm{m} / \mathrm{z}, 552$ and 554), we believe that they may also belong to the lipid group based on their isotopic ion distribution profile. This result led us to speculate that nematode infection might modulate the lipid bilayer to facilitate diffusion of molecules in gall cells during nematode parasitism. Also, lipids or their precursors present in galls may act as signaling molecules. In addition, inositol phospholipids are involved in the regulation and activation of cell proliferation in plants (Connett and Hanke 1986; Heim and Wagner 1986) and, maybe, expanding galls. Thus, nematode parasitism may involve modulation of cell metabolism through generation of secondary messengers produced from lipids constituting a lipid bilayer. A full characterization of these lipid structures may help us to identify metabolite pathways involved in the nematode infection or maintenance process.

Here, we performed the partial characterization of three GPC structures. All interpreted spectra have the fragment ion at $\mathrm{m} / \mathrm{z}$ 184, a diagnostic fragment for GPC (Stübiger et al. 2008), corresponding to PC. The fragmentation performed for other precursor ions identified from the lipid extract revealed the same diagnostic fragment, suggesting that these are GPC as well. This evidence supports the reliability of the structures predicted based on the mass value, isotopic distribution pattern, and chemical nature. More robust analyses such as liquid chromatography (LC)-MS experiments can be performed to further characterize other LMWI identified from MALDI-MSI procedures.

\section{MALDI-MSI of LMWI performed after DHB sublimation revealed one molecule present exclusively in nematode-infected roots.}

Only when MALDI-MSI of LMWI was performed in roots and galls applying 2,5-DHB matrix by sublimation were we able to identify an LMWI exclusively present in galls $(\mathrm{m} / \mathrm{z}$ 235.2). It will be interesting to perform chromatography and MS to elucidate the structure of this molecule and infer its biological significance. The use of other matrices might also potentially reveal different LMWI present only in galls. MALDIMSI has been used to map metabolites in roots and nodules of M. truncatula during nitrogen fixation, identifying 19 molecules after DHB coating deposition (Ye et al. 2013). Only the ion at $\mathrm{m} / \mathrm{z}$ 104.18 related to choline correlated with our observations of LMWI analysis in galls and uninfected roots. In addition, gas chromatography MS and nuclear magnetic resonance analysis have been used for the identification of metabolites from leaves

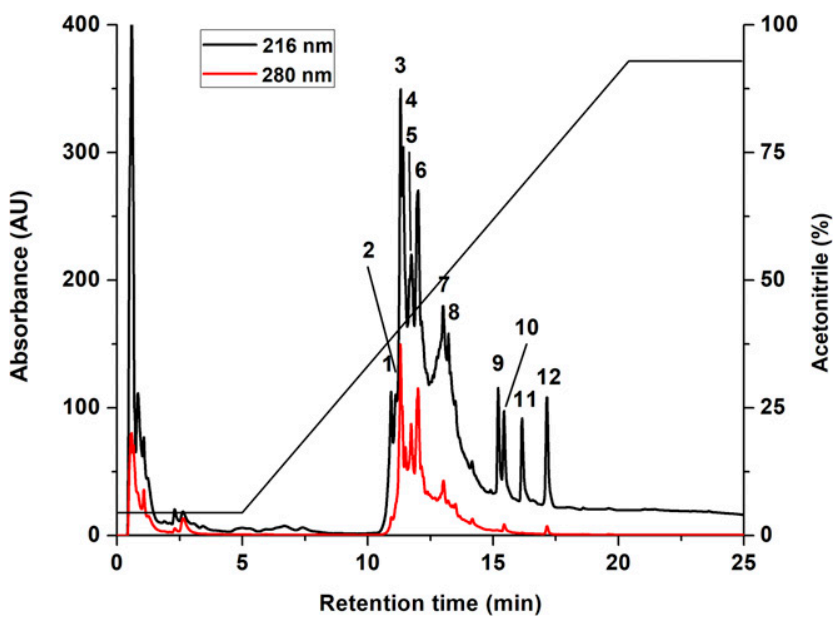

Fig. 6. Ultrafast liquid chromatography of proteins extracts obtained from galls. Numbers indicate the fractions identified. 
and stems of tomato plants (Eloh et al. 2016) and roots of Medicago truncatula (Baldacci-Cresp et al. 2015). Amino acids and sugars were the molecules more abundantly characterized and differentially identified using these approaches. The application of different methodologies is important for comparative analyses and to generate additional data, helping scientists to decipher metabolic changes and adjustments occurring during RKN-plant interaction.

\section{Isolation of proteins identified by MALDI-MSI in galls infected by Meloidogyne incognita.}

Previous work described proteomic strategies applied to study the mechanisms of plant-nematode interaction, focusing on identification of large proteins of more than $10 \mathrm{kDa}$ (Calvo et al. 2005; Franco et al. 2010; Ledger et al. 2002; Navas et al. 2002; Villeth et al. 2015). In our experiments, we isolated peptides and proteins ranging from $\mathrm{m} / \mathrm{z} 3,441.9$ to 11,520.6, even when some ions can represent a $[\mathrm{M}+2 \mathrm{H}]^{2+}$ adduct. We showed that, using a simple extraction procedure, polypeptides identified by our HMWI MALDI-MSI analysis can be potentially obtained to characterize candidate ions. The use of chromatography followed by MALDI-TOF-MS for a comparison between polypeptides from uninfected roots and galls must be performed under the approach where proteins are digested by proteolysis before analysis. This is needed because the mass resolution in the linear mode is inefficient to distinguish between high masses of close value. Alternatively, accurate data can be obtained using a high-resolution mass spectrometer such as an ESI-Q-TOF. The chromatographic strategy used here can be improved, using an enhanced separation of the molecules by applying LC-MS or nano LC-MS analysis when more peptides and proteins can be accurately detected. Future experiments should be employed to isolate and elucidate the structure of the target ions identified by MALDI-MSI to infer a potential function in the formation and maintenance of nematode-induced feeding sites.

\section{Concluding remarks.}

MALDI-MSI technology is an attractive tool with which to study the presence or absence of molecular components in complex plant tissues such as RKN-induced galls. This tool is unique for guiding the selection and characterization of secondary metabolites and polypeptides aimed at elucidating the biological processes involved during the plant-nematode interaction. First, sample preparation was a critical step for the use of this technique, and the use of egg yolk followed by cryosection preparation proved to be essential to keep plant compounds in their original locations. Our experimental settings allowed us to obtain images from root and gall sections without contamination of exogenous ions or diffusion of molecules and to faithfully map HMWI as well as LMWI in roots and galls. We identified LMWI present in galls and roots, with one ion exclusively present in nematode feeding sites and others exclusively in uninfected roots that we believe to be phospholipids. MALDI-MSI acquisitions of LMWI in the fragmentation mode (MS/MS) will help to elucidate the structure of some ions identified. In addition, it will be interesting to verify whether components secreted by the nematodes during parasitism can be detected within giant cells during parasitism.

Moreover, in future work, sample preparation as described here can be applied for experiments of HMWI imaging using a mass spectrometer with higher resolution, such as MALDIFurrier Transform-MSI or desorption ESI-MSI. As such, masses of HMWI identified in infected and uninfected roots can be measured with even higher accuracy to determine peptide and protein structures.

\section{MATERIALS AND METHODS}

\section{Reagents.}

Calibrant mixture (Protein Calibration Standard I and Peptide Calibration Standard II), $\alpha$-cyano-4-hydroxycinnamic acid ( $\alpha$-cyano), and 2,5-DHB were purchased from Bruker Daltonics. The SA was purchased from Sigma. All other reagents were of spectrometry and chromatography grade.

\section{Plant growth and nematode inoculation.}

Seed of tomato cultivar Santa Cruz were sown in a seed bag containing sterile soil in a proportion of two parts of sand and one part of clay (2:1). The seed bag was placed in a greenhouse under a controlled temperature, with a maximum of $30^{\circ} \mathrm{C}$. After 15 days, tomato seedlings were transplanted to sterile soil (2:1)

Table 2. Average mass values identified by linear matrix-assisted laser desorption/ionization (MALDI) time-of-flight mass spectrometry performed on chromatographic fractions obtained from gall extracts 14 days after inoculation

\begin{tabular}{|c|c|c|c|c|c|c|c|c|c|c|c|}
\hline \multicolumn{12}{|c|}{ Values of $m / z$ per fraction ${ }^{a}$} \\
\hline 1 & 2 & 3 & 4 & 5 & 6 & 7 & 8 & 9 & 10 & 11 & 12 \\
\hline 3,442 & 3,443 & 3,441 & 3,980 & 3,547 & $\mathbf{3 , 6 3 8}$ & 3,786 & 4,091 & 3,640 & 3,442 & 3,443 & 3,368 \\
\hline 3,973 & 4,128 & 3,970 & 4,103 & 3,619 & 3,785 & 4,863 & 4,125 & $\mathbf{3 , 7 8 8}$ & 4,303 & 4,128 & 4,303 \\
\hline 4,128 & 5,062 & 3,979 & 4,127 & 3,660 & 4,863 & 5,794 & 4,352 & 4,096 & $\mathbf{4 , 5 3 2}$ & 4,304 & 4,532 \\
\hline 4,303 & 5,430 & 4,126 & 4,846 & 3,733 & 5,792 & $\ldots$ & 4,385 & 4,298 & 5,593 & 4,533 & 5,381 \\
\hline 5,064 & 5,593 & 5,059 & 4,862 & 3,919 & $\ldots$ & $\ldots$ & 5,058 & 4,356 & 5,795 & 5,063 & 5,591 \\
\hline 5,594 & 5,795 & 5,230 & 5,061 & 4,103 & $\ldots$ & $\ldots$ & 5,229 & 5,795 & 6,734 & 5,384 & 5,794 \\
\hline 5,698 & 5,815 & 5,378 & 5,149 & 4,836 & $\ldots$ & $\ldots$ & 5,377 & 8,219 & 7,610 & 5,795 & 6,025 \\
\hline 5,795 & 5,836 & 5,402 & 5,214 & 4,845 & $\ldots$ & $\ldots$ & 5,790 & $\ldots$ & 7,670 & 7,611 & 6,737 \\
\hline 7,529 & 5,856 & 5,695 & 5,378 & 4,862 & $\ldots$ & $\ldots$ & 20,336 & $\ldots$ & 8,216 & 7,674 & 7,514 \\
\hline 7,610 & 6,025 & 5,791 & 5,590 & 4,875 & $\ldots$ & $\ldots$ & 20,434 & $\ldots$ & 8,245 & 8,026 & 7,609 \\
\hline 8,213 & 7,611 & 5,813 & 5,793 & 5,618 & $\ldots$ & $\ldots$ & $\ldots$ & $\ldots$ & 8,589 & 8,219 & 7,670 \\
\hline 8,606 & 7,635 & 5,828 & 5,814 & 7,607 & $\ldots$ & $\ldots$ & $\ldots$ & $\ldots$ & 8,605 & 8,247 & 8,217 \\
\hline 11,518 & 7,660 & 7,604 & 7,608 & 8,601 & $\ldots$ & $\ldots$ & $\ldots$ & $\ldots$ & 8,811 & 8,607 & 8,245 \\
\hline$\ldots$ & 8,218 & 8,212 & 8,602 & $\ldots$ & $\ldots$ & $\ldots$ & $\ldots$ & $\ldots$ & $\ldots$ & 8,631 & 8,604 \\
\hline$\ldots$ & 8,248 & 8,239 & $\ldots$ & $\ldots$ & $\ldots$ & $\ldots$ & $\ldots$ & $\ldots$ & $\ldots$ & 8,741 & 8,624 \\
\hline$\ldots$ & 8,606 & 10,866 & $\ldots$ & $\ldots$ & $\ldots$ & $\ldots$ & $\ldots$ & $\ldots$ & $\ldots$ & 8,812 & 8,735 \\
\hline$\ldots$ & 11,521 & 11,361 & $\ldots$ & $\ldots$ & $\ldots$ & $\ldots$ & $\ldots$ & $\ldots$ & $\ldots$ & $\ldots$ & 10,875 \\
\hline$\ldots$ & $\ldots$ & 11,377 & $\ldots$ & $\ldots$ & $\ldots$ & $\ldots$ & $\ldots$ & $\ldots$ & $\ldots$ & $\ldots$ & $\ldots$ \\
\hline$\ldots$ & $\ldots$ & 11,393 & $\ldots$ & $\ldots$ & $\ldots$ & $\ldots$ & $\ldots$ & $\ldots$ & $\ldots$ & $\ldots$ & $\ldots$ \\
\hline$\ldots$ & $\ldots$ & 11,401 & $\ldots$ & $\ldots$ & $\ldots$ & $\ldots$ & $\ldots$ & $\ldots$ & $\ldots$ & $\ldots$ & $\ldots$ \\
\hline
\end{tabular}

\footnotetext{
${ }^{a}$ Ions whose values match those identified in MALDI mass spectrometry imaging experiments are marked in bold.
} 
in single pots. Thirty-day-old plants were then inoculated with 700 freshly hatched second-stage juveniles Meloidogyne incognita.

\section{Tissue sections.}

Infected and noninfected (control) roots were collected at 14 to $30 \mathrm{DAI}$ and the galls dissected from roots were submitted to two sectioning procedures.

Fresh galls and uninfected roots were gradually dehydrated in 30,60, and $90 \%$ ethanol and mounted in 3\% agarose. Sections of 50 to $300 \mu \mathrm{m}$ were made with a vibratome (Vibratome 3000 EP; MyNeuroLab). Tissue slices were first mounted on a glass slide for microscopic observations and images were taken with a digital camera (Axiocam; Zeiss). After that, tissues were transferred and attached to a MALDI target plate using an electrical conductive double-sided adhesive tape (3M) and imaged again using the same digital camera coupled to a magnifying glass.

Fresh galls and uninfected roots were mounted in an egg block, as previously described by Sosnowski et al. (2015), in $10 \%$ gelatin or $5 \%$ agarose. Subsequently, samples were gradually cooled for $1 \mathrm{~h}$ at $4^{\circ} \mathrm{C}$ and then for $1 \mathrm{~h}$ at $-20^{\circ} \mathrm{C}$, and stored overnight at $-80^{\circ} \mathrm{C}$. Sections of 10 to $90 \mu \mathrm{m}$ were generated at $-15^{\circ} \mathrm{C}$ using a cryostat (HYREX C50; Zeiss) in a chamber maintained at $-35^{\circ} \mathrm{C}$. Tissue sections were thaw mounted on ITO glass slides (Bruker Daltonics), dried in a vacuum desiccator, and stored at $-80^{\circ} \mathrm{C}$. Microscopy analyses were performed using brightfield optics and images were obtained with a digital camera (Axiocam; Zeiss).

\section{MALDI-MSI of HMWI.}

Tissue sections were defrosted, dried in a vacuum desiccator for $10 \mathrm{~min}$, and washed for $30 \mathrm{~s}$ in a chloroform/isopropanol solution (1:1). The following matrix solutions were tested: SA, $\alpha$-cyano, and 2,5-DHB. The matrixes were sprayed over the whole tissue section using an artistic airbrush (Lee Pro Tools 601115 ) connected to nitrogen gas. For this, 20 to 30 cycles of matrix application were composed of short 1- to 2-s sprays deposited $30 \mathrm{~cm}$ over a slide at 10 -s intervals.

MALDI-MSI of HMWI was performed using an UltraFlex III mass spectrometer (Bruker Daltonics) in the linear-positive mode, with constant laser (solid-state) intensity, 60- $\mu \mathrm{m}$ resolution, and in the $\mathrm{m} / \mathrm{z}$ range of 2,000 to 15,000 . The mass spectrometer was calibrated using a drop of Protein Calibration Standard I applied to a tissue section. Automatic scanning steps were accomplished using the Flex Imaging 4.0 software. Global spectra were generated for each image from 100 laser shots at each position in the global maps.

\section{MALDI-MSI of LMWI.}

Tissue sections were defrosted and dried in a vacuum desiccator for $10 \mathrm{~min}$, then washed for $30 \mathrm{~s}$ in a chloroform/isopropanol solution (1:1). For acquisition of LMWI, two strategies were performed: no matrix deposition and 2,5-DHB deposition by sublimation using a home-built device. The deposited amount of DHB was $14 \mathrm{mg} /$ slice. MALDI-MSI of LMWI without matrix deposition was performed on an UltraFlex Xtreme mass spectrometer (Bruker Daltonics) in the reflective-positive mode, with constant laser (solid-state) intensity, 60- $\mu \mathrm{m}$ resolution, and in the $\mathrm{m} / \mathrm{z}$ range of 70 to 1,500 . The mass spectrometer was calibrated according to adducts of $\alpha$-cyano matrix, applied on a specific tissue section. Automatic scanning steps were accomplished using FlexImaging 4.0 software. Global spectra were generated for each image from 1,000 laser shots at each position within the global maps. MALDI-MSI of LMWI carryout after DHB sublimation was performed on a Rapidflex MALDI tissue typer mass spectrometer (Bruker
Daltonics) in a reflective-positive mode with constant laser (solid-state) intensity, $10 \mu \mathrm{m}$ of resolution, and in the $\mathrm{m} / \mathrm{z}$ range of 100 to 1,400 . The mass spectrometer was calibrated using Peptide Calibration Standard II (Bruker Daltonics). Automatic scanning steps were accomplished using FlexImaging 5.0 software. The global spectrum was generated for each image from 200 laser shots at each position in the global maps.

\section{Lipid extraction and analysis.}

A pool of uninfected roots representing the same developmental stage as those used for other analyses was converted into powder, of which $3 \mathrm{mg}$ was used for lipid extraction according to Ren et al. (2017), with minor modifications. Briefly, $500 \mu \mathrm{l}$ of methanol, $250 \mu \mathrm{l}$ of chloroform, and $500 \mu \mathrm{l}$ of Milli-Q water were mixed to root powder in a 1.8-ml tube and subjected to an ultrasound treatment on ice water for $20 \mathrm{~min}$. Another $250 \mu \mathrm{l}$ of chloroform was added to the mixture and sonicated for $10 \mathrm{~min}$. The mixture was centrifuged at 4,000 rpm for $5 \mathrm{~min}$ and the lower layer, consisting of chloroform containing the extracted lipids, was pipetted out and evaporated in a speed-vac.

The lipid extract was dissolved in $30 \mu \mathrm{l}$ of acetonitrile, of which $1 \mu \mathrm{l}$ was mixed with $3 \mu \mathrm{l}$ of DHB matrix $(7.5 \mathrm{mg}$ in $250 \mu \mathrm{l}$ of ethanol/Milli-Q water [1:1] containing $100 \mathrm{mM} \mathrm{LiCl}$ ), and deposited on a MALDI plate. The molecular masses of the lipids were determined by MALDI-TOF-MS using an UltraFlex III mass spectrometer (Bruker Daltonics) in the reflective-positive mode controlled by the FlexControl software. The precursor ions were selected and fragmented using the LIFT mode (MS/MS). The spectrometer was calibrated using Peptide Calibration Standard I mixture and DHB ions before analysis. The mass range analyzed was between $\mathrm{m} / \mathrm{z} 100$ and 1,500. The mass spectra (MS and MS/MS) were analyzed using the FlexAnalysis 3.5 software.

The lipid extract was analyzed in an impact II Q-TOF mass spectrometer (Bruker Daltonics) coupled to an ESI ion source operating in the positive mode. The sample was dissolved in $150 \mu \mathrm{l}$ of a 1:4 chloroform/methanol solution containing $1 \mathrm{mM} \mathrm{LiCl}$ and injected directly into the ion source using a Hamilton syringe at a flow rate of $180 \mu \mathrm{l} / \mathrm{h}$. The ion source parameters were nebulizer $=0.4$ bar, dry gas $=4.0$ liters $/ \mathrm{min}$, dry heater $=200^{\circ} \mathrm{C}$, capillary $=4500 \mathrm{~V}$, and end plate offset $=$ $-500 \mathrm{~V}$. The mass range was between $\mathrm{m} / z, 100$ and 2,500. The spectrometer was calibrated using $\mathrm{Na}$ formate ions to achieve $\leq 0.2 \mathrm{ppm}$ of accuracy. The acquisitions were controlled by oTOFControl software (Bruker Daltonics) and results were analyzed using the Compass DataAnalysis 4.3 software (Bruker Daltonics).

\section{Protein extraction and analysis.}

A pool of galls of the same stage of development as used for other analyses (14 DAI) was converted into powder and $10 \mathrm{mg}$ of this powder was used for protein extraction with a water/ acetonitrile mixture (1:1). The solution was vigorously vortexed for $3 \mathrm{~min}$, then centrifuged for $15 \mathrm{~min}$. The supernatant was transferred to another tube and, after freezing, the sample was dried using a speed-vac (Labconco).

The separation of the extract content obtained from galls was performed by injecting $10 \mu \mathrm{l}$ of an aqueous solution of $30 \mu \mathrm{g} / \mu \mathrm{l}$ into a reverse-phase Shim-pack column XR-ODS (2.0 $\mathrm{mm}$ i.d. by $50 \mathrm{~mm}$; Shimadzu Co.) in a UFLC LC-20AD system (Shimadzu Co.). A linear gradient of 5 to $95 \%$ of acetonitrile was performed over $20 \mathrm{~min}$, with a flow rate of $0.4 \mathrm{ml} / \mathrm{min}$. Chromatographic fractions, monitored at 216 and $280 \mathrm{~nm}$, were manually collected, frozen, and dried using a speed-vac (Labconco). 
The chromatographic fractions were dissolved using Milli-Q water according to the absorbance intensity (10 to $50 \mu \mathrm{l})$. Solution corresponding to chromatography fractions $(1 \mu \mathrm{l})$ was mixed with $3 \mu \mathrm{l}$ of $\alpha$-cyano matrix ( $5 \mathrm{mg}$ in $500 \mu \mathrm{l}$ of ethanol/ Milli-Q water [1:1] containing $1 \%$ triflouroacetic acid) and deposited on a MALDI plate. The molecular masses of the proteins were determined by MALDI-TOF-MS using an UltraFlex III mass spectrometer (Bruker Daltonics) in the linear-positive mode controlled by the FlexControl software. The spectrometer was calibrated using a Protein Calibration Standard I mixture before analysis. The mass range analyzed was between $\mathrm{m} / \mathrm{z}$ 2,500 and 15,000 . The mass spectra were analyzed using the FlexAnalysis 3.5 software.

\section{ACKNOWLEDGMENTS}

We thank S. A. S. Kuckelhaus and T. K. dos Santos Borges for the use of cryostat at the LCI, UnB. We are also grateful to EMBRAPA.

\section{LITERATURE CITED}

Bach, R. O., and Gallicchio, V. S., eds. 1990. Lithium and Cell Physiology, 1 st ed. Springer-Verlag, New York.

Baldacci-Cresp, F., Chang, C., Maucourt, M., Deborde, C., Hopkins, J., Lecomte, P., Bernillon, S., Brouquisse, R., Moing, A., Abad, P., Hérouart, D., Puppo, A., Favery, B., and Frendo, P. 2012. (Homo)glutathione deficiency impairs root-knot nematode development in Medicago truncatula. PLoS Pathog. 8:e1002471.

Baldacci-Cresp, F., Maucourt, M., Deborde, C., Pierre, O., Moing, A., Brouquisse, R., Favery, B., and Frendo, P. 2015. Maturation of nematode-induced galls in Medicago truncatula is related to water status and primary metabolism modifications. Plant Sci. 232:77-85.

Banora, M. Y., Rodiuc, N., Baldacci-Cresp, F., Smertenko, A., BleveZacheo, T., Mellilo, M. T., Karimi, M., Hilson, P., Evrard, J.-L., Favery, B., Engler, G., Abad, P., and de Almeida Engler, J. 2011. Feeding cells induced by phytoparasitic nematodes require $\gamma$-tubulin ring complex for microtubule reorganization. PLoS Pathog. 7:e1002343.

Barbosa, E. A., Iembo, T., Martins, G. R., Silva, L. P., Prates, M. V., Andrade, A. C., and Bloch, C., Jr. 2015. Skin secretion peptides: The molecular facet of the deimatic behavior of the four-eyed frog, Physalaemus nattereri (Anura, Leptodactylidae). Rapid Commun. Mass Spectrom. 29:2061-2068.

Barcala, M., Fenoll, C., and Escobar, C. 2012. Laser microdissection of cells and isolation of high-quality RNA after cryosectioning. Methods Mol. Biol. 883:87-95.

Barcala, M., García, A., Cabrera, J., Casson, S., Lindsey, K., Favery, B., García-Casado, G., Solano, R., Fenoll, C. and Escobar, C. 2010. Early transcriptomic events in microdissected Arabidopsis nematode-induced giant cells. Plant J. 61:698-712.

Becker, L., Carré, V., Poutaraud, A., Merdinoglu, D., and Chaimbault, P. 2014. MALDI mass spectrometry imaging for the simultaneous location of resveratrol, pterostilbene and viniferins on grapevine leaves. Molecules 19:10587-10600.

Bencivenni, M., Faccini, A., Zecchi, R., Boscaro, F., Moneti, G., Dossena, A., and Sforza, S. 2014. Electrospray MS and MALDI imaging show that nonspecific lipid-transfer proteins (LTPs) in tomato are present as several isoforms and are concentrated in seeds. J. Mass Spectrom. 49:1264-1271.

Brand, G. D., Krause, F. C., Silva, L. P., Leite, J. R. S. A., Melo, J. A. T., Prates, M. V., Pesquero, J. B., Santos, E. L., Nakaie, C. R., Costa-Neto, C. M., and Bloch, C., Jr. 2006. Bradykinin-related peptides from Phyllomedusa hypochondrialis. Peptides 27:2137-2146.

Calvo, E., Flores-Romero, P., López, J. A., and Navas, A. 2005. Identification of proteins expressing differences among isolates of Meloidogyne spp. (Nematoda: Meloidogynidae) by nano-liquid chromatography coupled to ion-trap mass spectrometry. J. Proteome Res. 4: 1017-1021.

Caprioli, R. M., Farmer, T. B., and Gile, J. 1997. Molecular imaging of biological samples: Localization of peptides and proteins using MALDITOF MS. Anal. Chem. 69:4751-4760.

Cerruti, C. D., Touboul, D., Guérineau, V., Petit, V. W., Laprévote, O., and Brunelle, A. 2011. MALDI imaging mass spectrometry of lipids by adding lithium salts to the matrix solution. Anal. Bioanal. Chem. 401:75-87.

Chaurand, P., Norris, J. L., Cornett, D. S., Mobley, J. A., and Caprioli, R. M. 2006. New developments in profiling and imaging of proteins from tissue sections by MALDI mass spectrometry. J. Proteome Res. 5: 2889-2900.

Chaurand, P., Stoeckli, M., and Caprioli, R. M. 1999. Direct profiling of proteins in biological tissue sections by MALDI mass spectrometry. Anal. Chem. 71:5263-5270.

Cheng, A.-X., Lou, Y.-G., Mao, Y.-B., Lu, S., Wang, L.-J., and Chen, X.-Y. 2007. Plant terpenoids: Biosynthesis and ecological functions. J. Integr. Plant Biol. 49:179-186.

Clément, M., Ketelaar, T., Rodiuc, N., Banora, M. Y., Smertenko, A., Engler, G., Abad, P., Hussey, P. J., and de Almeida Engler, J. 2009. Actin-depolymerizing factor2-mediated actin dynamics are essential for root-knot nematode infection of Arabidopsis. Plant Cell 21:2963-2979.

Connett, R. J., and Hanke, D. E. 1986. Breakdown of phosphatidylinositol in soybean callus. Planta 169:216-221.

Cvačka, J., and Svatoš, A. 2003. Matrix-assisted laser desorption/ionization analysis of lipids and high molecular weight hydrocarbons with lithium 2,5-dihydroxybenzoate matrix. Rapid Commun. Mass Spectrom. 17: 2203-2207.

de Almeida Engler, J., De Veylder, L., De Groodt, R., Rombauts, S., Boudolf, V., De Meyer, B., Hemerly, A., Ferreira, P., Beeckman, T., Karimi, M., Hilson, P., Inzé, D., and Engler, G. 2009. Systematic analysis of cell-cycle gene expression during Arabidopsis development. Plant J. 59:645-660.

de Almeida Engler, J., De Vleesschauwer, V., Burssens, S., Celenza, J. L., Jr., Inzé, D., Van Montagu, M., Engler, G., and Gheysen, G. 1999 Molecular markers and cell cycle inhibitors show the importance of cell cycle progression in nematode-induced galls and syncytia. Plant Cell 11: 793-808.

de Almeida Engler, J., Kyndt, T., Vieira, P., Van Cappelle, E., Boudolf, V., Sanchez, V., Escobar, C., De Veylder, L., Engler, G., Abad, P., and Gheysen, G. 2012. CCS52 and DEL1 genes are key components of the endocycle in nematode-induced feeding sites. Plant J. 72:185-198.

de Almeida Engler, J., Van Poucke, K., Karimi, M., De Groodt, R., Gheysen, G., Engler, G. and Gheysen, G. 2004. Dynamic cytoskeleton rearrangements in giant cells and syncytia of nematode-infected roots. Plant J. 38:12-26.

Dong, Y., Li, B., Malitsky, S., Rogachev, I., Aharoni, A., Kaftan, F., Svatoš, A., and Franceschi, P. 2016. Sample preparation for mass spectrometry imaging of plant tissues: A review. Front. Plant Sci. 7:60.

Eloh, K., Sasanelli, N., Maxia, A., and Caboni, P. 2016. Untargeted metabolomics of tomato plants after root-knot nematode infestation. J. Agric. Food Chem. 64:5963-5968.

Franceschi, P., Dong, Y., Strupat, K., Vrhovsek, U., and Mattivi, F. 2012. Combining intensity correlation analysis and MALDI imaging to study the distribution of flavonols and dihydrochalcones in Golden Delicious apples. J. Exp. Bot. 63:1123-1133.

Franco, O. L., Pereira, J. L., Costa, P. H. A., Rocha, T. L., Albuquerque, É. V. S., Grossi-de-Sá, M. F., Carneiro, R. M. D. G., Carneiro, R. G., and Mehta, A. 2010. Methodological evaluation of 2-DE to study root proteomics during nematode infection in cotton and coffee plants. Prep. Biochem. Biotechnol. 40:152-163.

Fujimoto, T., Mizukubo, T., Abe, H. and Seo, S. 2015. Sclareol induces plant resistance to root-knot nematode partially through ethylene-dependent enhancement of lignin accumulation. Mol. Plant-Microbe Interact. 28:398-407.

Gemperline, E., Keller, C., Jayaraman, D., Maeda, J., Sussman, M. R., Ané, J.-M., and Li, L. 2016. Examination of endogenous peptides in Medicago truncatula using mass spectrometry imaging. J. Proteome Res. 15: 4403-4411.

Grassl, J., Taylor, N. L., and Millar, A. H. 2011. Matrix-assisted laser desorption/ionisation mass spectrometry imaging and its development for plant protein imaging. Plant Methods 7:21.

Heim, S., and Wagner, K. G. 1986. Evidence of phosphorylated phosphatidylinositols in the growth cycle of suspension cultured plant cells. Biochem. Biophys. Res. Commun. 134:1175-1181.

Hofmann, J., Youssef-Banora, M., de Almeida-Engler, J., and Grundler, F. M. W. 2010. The role of callose deposition along plasmodesmata in nematode feeding sites. Mol. Plant-Microbe Interact. 23:549-557.

Horn, P. J., James, C. N., Gidda, S. K., Kilaru, A., Dyer, J. M., Mullen, R. T., Ohlrogge, J. B., and Chapman, K. D. 2013. Identification of a new class of lipid droplet-associated proteins in plants. Plant Physiol. 162: 1926-1936

Horn, P. J., Korte, A. R., Neogi, P. B., Love, E., Fuchs, J., Strupat, K., Borisjuk, L., Shulaev, V., Lee, Y.-J., and Chapman, K. D. 2012. Spatial mapping of lipids at cellular resolution in embryos of cotton. Plant Cell 24:622-636.

Ibáñez, C., García-Cañas, V., Valdés, A., and Simó, C. 2013. Novel MSbased approaches and applications in food metabolomics. Trends Analyt Chem. 52:100-111. 
Jones, M. G. K. 1981. Host cell responses to endoparasitic nematode attack: Structure and function of giant cells and syncytia. Ann. Appl. Biol. 97:353-372.

Jones, M. G. K., and Northcote, D. H. 1972. Multinucleate transfer cells induced in coleus roots by the root-knot nematode, Meloidogyne arenaria. Protoplasma 75:381-395.

Kaftan, F., Vrkoslav, V., Kynast, P., Kulkarni, P., Böcker, S., Cvačka, J., Knaden, M., and Svatoš, A. 2014. Mass spectrometry imaging of surface lipids on intact Drosophila melanogaster flies. J. Mass Spectrom. 49:223-232.

Kaspar, S., Peukert, M., Svatos, A., Matros, A., and Mock, H.-P. 2011. MALDI-imaging mass spectrometry-An emerging technique in plant biology. Proteomics 11:1840-1850.

Kunst, L., and Samuels, A. L. 2003. Biosynthesis and secretion of plant cuticular wax. Prog. Lipid Res. 42:51-80.

Kusari, S., Lamshöft, M., Kusari, P., Gottfried, S., Zühlke, S., Louven, K., Hentschel, U., Kayser, O., and Spiteller, M. 2014. Endophytes are hidden producers of maytansine in Putterlickia roots. J. Nat. Prod. 77:2577-2584.

Ledger, T. N., Laffaire, J. B., Piotte, C., and Abad, P. 2002. Direct identification of stylet secreted proteins from root-knot nematodes by a proteomic approach. Proteins 121:205-211.

Lee, Y. J., Perdian, D. C., Song, Z., Yeung, E. S., and Nikolau, B. J. 2012. Use of mass spectrometry for imaging metabolites in plants. Plant J. 70:81-95.

Lu, L., Yue, H., Song, F., Tsao, R., Liu, Z., and Liu, S. 2010. Rapid profiling of alkaloids in several medicinal herbs by matrix-assisted laser desorption/ionization mass spectrometry. Chem. Res. Chin. Univ. 26:11-16.

Magalhães, B. S., Melo, J. A. T., Leite, J. R. S. A., Silva, L. P., Prates, M. V., Vinecky, F., Barbosa, E. A., Verly, R. M., Mehta, A., Nicoli, J. R., Bemquerer, M. P., Andrade, A. C., and Bloch, C., Jr. 2008. Post-secretory events alter the peptide content of the skin secretion of Hypsiboas raniceps. Biochem. Biophys. Res. Commun. 377:1057-1061.

Mullen, A. K., Clench, M. R., Crosland, S., and Sharples, K. R. 2005. Determination of agrochemical compounds in soya plants by imaging matrix-assisted laser desorption/ionisation mass spectrometry. Rapid Commun. Mass Spectrom. 19:2507-2516.

Navas, A., López, J. A., Espárrago, G., Camafeita, E., and Albar, J. P. 2002. Protein variability in Meloidogyne spp. (Nematoda: Meloidogynidae) revealed by two-dimensional gel electrophoresis and mass spectrometry. J. Proteome Res. 1:421-427.

Peukert, M., Becker, M., Matros, A., and Mock, H.-P. 2014. Mass spectrometry-based imaging of metabolites and proteins. Methods Mol. Biol. 1072:223-240.

Portillo, M., Cabrera, J., Lindsey, K., Topping, J., Andrés, M. F., Emiliozzi, M., Oliveros, J. C., García-Casado, G., Solano, R., Koltai, H., Resnick, N., Fenoll, C., and Escobar, C. 2013. Distinct and conserved transcriptomic changes during nematode-induced giant cell development in tomato compared with Arabidopsis: A functional role for gene repression. New Phytol. 197:1276-1290.

Ren, X., Zhao, X., Turcotte, F., Deschênes, J.-S., Tremblay, R., and Jolicoeur, M. 2017. Current lipid extraction methods are significantly enhanced adding a water treatment step in Chlorella protothecoides. Microb. Cell Fact. 16:26.

Schrauzer, G. N. 2002. Lithium: Occurrence, dietary intakes, nutritional essentiality. J. Am. Coll. Nutr. 21:14-21.

Shukla, N., Yadav, R., Kaur, P., Rasmussen, S., Goel, S., Agarwal, M., Jagannath, A., Gupta, R., and Kumar, A. 2018. Transcriptome analysis of root-knot nematode (Meloidogyne incognita)-infected tomato (Solanum lycopersicum) roots reveals complex gene expression profiles and metabolic networks of both host and nematode during susceptible and resistance responses. Mol. Plant Pathol. 19:615-633.

Soares, M. S., da Silva, D. F., Forim, M. R., da Silva, M. F., Fernandes, J. B., Vieira, P. C., Silva, D. B., Lopes, N. P., de Carvalho, S. A., de Souza,
A. A., and Machado, M. A. 2015. Quantification and localization of hesperidin and rutin in Citrus sinensis grafted on C. limonia after Xylella fastidiosa infection by HPLC-UV and MALDI imaging mass spectrometry. Phytochemistry 115:161-170.

Sosnowski, P., Zera, T., Wilenska, B., Szczepanska-Sadowska, E., and Misicka, A. 2015. Imaging and identification of endogenous peptides from rat pituitary embedded in egg yolk. Rapid Commun. Mass Spectrom. 29:327-335.

Stübiger, G., Pittenauer, E., and Allmaier, G. 2008. MALDI seamless postsource decay fragment ion analysis of sodiated and lithiated phospholipids. Anal. Chem. 80:1664-1678.

Sud, M., Fahy, E., Cotter, D., Brown, A., Dennis, E. A., Glass, C. K., Merrill, A. H., Jr., Murphy, R. C., Raetz, C. R. H., Russell, D. W., and Subramaniam, S. 2007. LMSD: LIPID MAPS structure database. Nucleic Acids Res. 35:D527-D532.

Veličković, D., Ropartz, D., Guillon, F., Saulnier, L., and Rogniaux, H. 2014. New insights into the structural and spatial variability of cellwall polysaccharides during wheat grain development, as revealed through MALDI mass spectrometry imaging. J. Exp. Bot. 65:20792091.

Vieira, P., Banora, M. Y., Castagnone-Sereno, P., Rosso, M.-N., Engler, G., and de Almeida Engler, J. 2012. An immunocytochemical procedure for protein localization in various nematode life stages combined with plant tissues using methylacrylate-embedded specimens. Phytopathology 102: 990-996.

Vieira, P., Escudero, C., Rodiuc, N., Boruc, J., Russinova, E., Glab, N., Mota, M., De Veylder, L., Abad, P., Engler, G., and de Almeida Engler, J. 2013. Ectopic expression of Kip-related proteins restrains root-knot nematode-feeding site expansion. New Phytol. 199:505-519.

Villeth, G. R. C., Carmo, L. S. T., Silva, L. P., Fontes, W., Grynberg, P., Saraiva, M., Brasileiro, A. C. M., Carneiro, R. M. D., Oliveira, J. T. A., Grossi-de-Sá, M. F., and Mehta, A. 2015. Cowpea-Meloidogyne incognita interaction: Root proteomic analysis during early stages of nematode infection. Proteomics 15:1746-1759.

Vogt, T. 2010. Phenylpropanoid biosynthesis. Mol. Plant 3:2-20.

Vrkoslav, V., Míková, R., and Cvačka, J. 2009. Characterization of natural wax esters by MALDI-TOF mass spectrometry. J. Mass Spectrom. 44: 101-110.

Vrkoslav, V., Muck, A., Cvačka, J., and Svatos, A. 2010. MALDI imaging of neutral cuticular lipids in insects and plants. J. Am. Soc. Mass Spectrom. 21:220-231.

Wang, W.-X., Kusari, S., Sezgin, S., Lamshöft, M., Kusari, P., Kayser, O., and Spiteller, M. 2015. Hexacyclopeptides secreted by an endophytic fungus Fusarium solani N06 act as crosstalk molecules in Narcissus tazetta. Appl. Microbiol. Biotechnol. 99:7651-7662.

Weiß, S., Bartsch, M., and Winkelmann, T. 2017. Transcriptomic analysis of molecular responses in Malus domestica 'M26' roots affected by apple replant disease. Plant Mol. Biol. 94:303-318.

Williamson, V., Wang, C., and Lower, S. 2009. Application of pluronic gel to the study of root-knot nematode behaviour. Nematology 11:453-464.

Ye, H., Gemperline, E., Venkateshwaran, M., Chen, R., Delaux, P.-M., Howes-Podoll, M., Ané, J.-M., and Li, L. 2013. MALDI mass spectrometry-assisted molecular imaging of metabolites during nitrogen fixation in the Medicago truncatula-Sinorhizobium meliloti symbiosis. Plant J. 75:130-145.

Zaima, N., Goto-Inoue, N., Hayasaka, T., and Setou, M. 2010. Application of imaging mass spectrometry for the analysis of Oryza sativa rice. Rapid Commun. Mass Spectrom. 24:2723-2729.

Ziegler, J., and Facchini, P. J. 2008. Alkaloid biosynthesis: Metabolism and trafficking. Annu. Rev. Plant Biol. 59:735-769. 